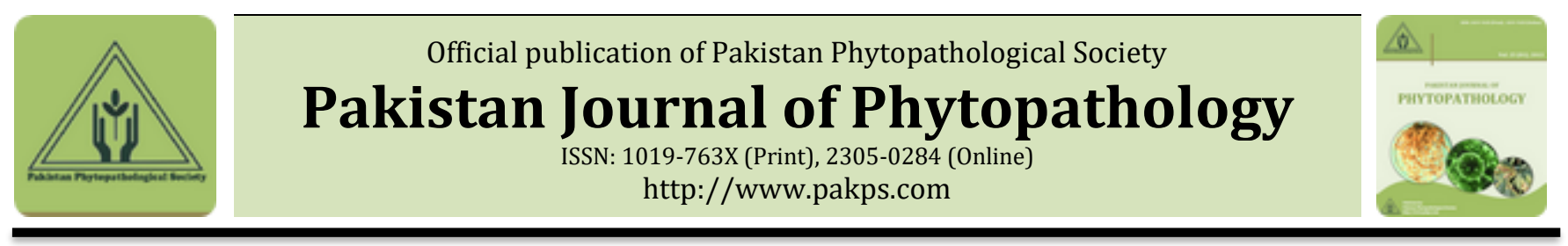

\title{
EFFECT OF DIFFERENT PLANT ACTIVATORS AGAINST RHIZOCTONIA SOLANI CAUSING ROOT ROT OF CHILLI
}

\author{
aMuhammad S. Baloch, aNasir A. Rajput*, aMuhammad Atiq, aAbdul Rehman, bamiya M. Khan, \\ aKhalid Naveed, aBabar Khan, aSana Ullah, aNoor M. Baloch \\ a Department of Plant Pathology, University of Agriculture, Faisalabad, Pakistan. \\ b Department of Plant Pathology, Bahauddin Zakariya University, Multan, Pakistan.
}

\begin{abstract}
A B S T R A C T
Chilli is an important horticultural crop all over the world. Root rot of chilli is the most important disease caused by Rhizoctonia solani responsible for immense losses. Systemic acquired resistance (SAR) acting as a significant part in the proficiency of plants to protect themselves by means of hyper-sensitive reaction (HR) of plants toward the destructive pathogens. Additionally, SAR reveals as long time defense approach that may be weeks to months or sometimes throughout the entire season. The aim of this study was to induce systemic acquired resistance (SAR) against $R$. solani in chilli crop. Five plant activators salicylic acid, potassium dihydrogen phosphate $\left(\mathrm{KH}_{2} \mathrm{PO}_{4}\right)$, dipotassium hydrogen phosphate $\left(\mathrm{K}_{2} \mathrm{HPO}_{4}\right)$, benzoic acid and citric acid were evaluated under Lab. and field conditions with three different concentrations (1, 2 and 3\%). Salicylic acid gave better result at 3\% concentration. After 3rd application, salicylic acid at 21 days interval expressed minimum disease incidence as compared to others treatments. At concentration of $3 \%$ after twenty-one days of spraying salicylic acid showed minimum disease incidence (9.667\%) followed by $\mathrm{KH}_{2} \mathrm{PO}_{4}(16.433 \%), \mathrm{K}_{2} \mathrm{HPO}_{4}$ (20.241\%), benzoic acid (23.367\%) and citric acid (28.667\%) while control expressed maximum disease incidence (86.467\%). So, it is concluded that salicylic acid gave better result than others treatments.
\end{abstract}

Keywords: Salicylic acid, Potassium dihydrogen phosphate $\left(\mathrm{KH}_{2} \mathrm{PO}_{4}\right)$, di-potassium hydrogen phosphate $\left(\mathrm{K}_{2} \mathrm{HPO}_{4}\right)$, benzoic acid and citric acid.

\section{INTRODUCTION}

Chilli (Capsicum annuum L.) is an economically important and most cultivated crop worldwide. It covers the area of 177, 6000 hectares in all over the world with total production of 718, 2000 tons (Singh, 2007). In Pakistan it is considered as a very valuable cash crop and cultivated over an area of 38.4 thousand hectares with annual production 53.7 thousand tones which contributes $1.5 \%$ share in the total GDP. Sindh is a major chilli producer province followed by Punjab and Baluchistan respectively (Hussain and Abid, 2011). It is constituent of different essential elements including

Submitted: March 30, 2018

Revised: May 02, 2018

Accepted for Publication: June 08, 2018

* Corresponding Author:

Email: nasirrajput81@gmail.com

(C) 2017 Pak. J. Phytopathol. All rights reserved. proteins, fibers, minerals, vitamins, fatty acids, carotenoids, capsaicinoids and some steam-volatile oils (Bosland and Votava, 2003). Fresh green and red chilli has an abundant source of vitamin $\mathrm{C}$ and A (Chandra et al., 2010; Chang et al., 2011).

Rhizoctonia root rot of chilli caused by Rhizoctonia solani is a major constraint to chilli production all over the world. $R$. solani is a soil borne plant pathogenic fungi with a wide host range (chilli, corn, alfalfa, soybean etc.) and distributed all over the world (Agrios, 2005). First time this fungus was reported on potato plants in 1858, by Julius Kuhn. It belong to family basidiomycete often produces sexual spores (basidiospores) which are mostly four in number. In nature, $R$. solani reproduce asexually by means of somatic mycelium. It occurs mostly in the start and mid of summer. Diseased plants characteristically seem in patches in the pot or field conditions. Different conditions are responsible for this 
disease including, soil moisture, type of soil and delayed emergence of plants. The disease is more common at seedling stage but also affects mature plants consequently sever crop losses. Defoliation, wilting, vascular discoloration and stunting growth are the most prominent symptoms of root rot of chilli (Sanogo, 2003). Currently, there is no commercially reliable hybrid variety of chilli having resistance against $R$. solani (Muhyi and Bosland, 1992).

Systemic acquired resistance (SAR) means of specific signals transferring pathway which play a significant role in the entire life of plants to defend themselves against destructive pathogens. When SAR path is activated, it's just an indication of disease and consequently plant develop necrotic lesion due to hypersensitive response (HR). SAR stimulates a broad range induction of systemic resistance in the plants (Hunt, 1996). SAR is a very useful approach and an inquisitive model for transducing signals. Understanding the biochemical variations consequences of cautious conditions which could permit the development of improved disease resistant transgene or else inventive sort of defensive plant chemicals act as stimuli in plant breeding and genetics for disease resistance tools (Ryals et al., 1996). The objective of this study was to manage the Rhizoctonia root rot by using different plant activators.

\section{MATERIALS AND METHODS}

This tentative work was conducted at Department of Plant Pathology, University of Agriculture, Faisalabad to evaluate systemic acquired resistant (SAR) through exogenous application of plant activators against Rhizoctonia root rot of chilli.

Collection of plant disease samples: Samples were collected on the basis of typical disease symptoms from the different localities of Faisalabad as well as Chiniot district and preserved in freezer at $4{ }^{\circ} \mathrm{C}$ for 5-7 days.

Isolation and pure culture of pathogen: Samples were surface sterilized with $5 \%$ bleach for 1 minute then washed three times with distilled water and plated on PDA medium. Pathogens were isolated from newly growing tip by using sterilized inoculating needle and

$$
\text { Root infection (\%) } \frac{\text { Total number of root pieces colonized by the fungus }}{\text { The total number of root pieces studies }} \times 100
$$

Field experiment: All plant activators were also evaluated under in field conditions against $R$. solani. The plot size was $5 \times 3 \mathrm{~m}^{2}$, there were 10 rows per plot with row to row distance of $30 \mathrm{~cm}$. The chilli seedlings were plated on sterilized PDA media. Plates were incubated at $25^{\circ} \mathrm{C} \pm 2^{\circ} \mathrm{C}$ and observed daily for checking growth of colonies in petri plates $(9 \mathrm{~cm}$ dia). Sub-culturing was done from single spore technique to obtain pure culture.

Preparation of plant activators concentrations: Salicylic acid, citric acid, benzoic acid, $\mathrm{KH}_{2} \mathrm{PO}_{4}$ and $\mathrm{K}_{2} \mathrm{HPO}_{4}$ were purchased from Lyallpur chemical company, Faisalabad. Three concentrations 1, 2 and $3 \%$ from each activator were prepared by dissolving in equal volumes of $\mathrm{ddH}_{2} \mathrm{O}$ and $\mathrm{C}_{2} \mathrm{H}_{6} \mathrm{O}$ by adjusting $\mathrm{pH} 7$ with $1 \mathrm{~N} \mathrm{NaOH}$.

In-vitro evaluation of different plant activators: $1 \mathrm{ml}$ concentration from each chemical was added and well distributed in Petri plates having diameter $5 \mathrm{~cm}$ with three replications, and then poured sterilized PDA even cover the bottom of the plate and gently shake to mix homogenously. Three days old culture of $R$. solani was selected for inoculation and $8 \mathrm{~mm}$ disks were seeded centrally in the Petri dishes then incubated at $27 \pm 1^{\circ} \mathrm{C}$. Three petri dishes without plant activators inoculation were kept as control. Each treatment was repeated thrice to reduce experimental error. The percentage reduction of growth (RG) ratio was calculated according to the following formula (Amer, 1995):

$$
\text { Reduction growth (\%) } \frac{\mathrm{RNT}-\mathrm{RT}}{\mathrm{RNT}} \times 100
$$

Where: RNT = Radius for non-treated media (control)

$\mathrm{RT}=$ Radius for treated media.

Effect of different plant activators on plant growth and disease development

Pot experiment: Seedlings of commonly grown variety of chilli (Sanam) were transplanted into earthen pots of $20 \mathrm{~cm}$ diameter; having $2 \mathrm{~kg}$ steam sterilized sandy clay loam soil. The soil was artificially infested with pathogen inoculum at $10^{4}$ conidia/g of soil before sowing (Zote et al., 1996). The soil was also amended with the plant activators and with three concentrations, i.e. 1, 2 and 3 $\%$. After transplanting, the sterilized water was applied to the seedlings. After 45 days, the plants were uprooted carefully and roots were washed with tap water. Data was recorded and root infection was calculated by following Formula. transplanted in the field and irrigated accordingly to maintain 50\% water holding capacity. After 3 weeks' different plant activators viz. Salicylic acid, Citric acid, Benzoic acid, $\mathrm{KH}_{2} \mathrm{PO}_{4}$ and $\mathrm{K}_{2} \mathrm{HPO}_{4}$ were sprayed at $1 \%$, 
$2 \%$ and $3 \%$ concentrations to induce Systemic Acquired Resistance (SAR) against $R$. solani and $2^{\text {nd }}$ spray was done after 14 days of first application. The treatments were repeated three times and control (without any treatment) was used for comparison. The application of plant activators was done early in the morning with the help of knapsack sprayer.

Collection of data: Data was recorded at 7 and 14 days of $1^{\text {st }}$ spray application and again 21 and 28 days after $2^{\text {nd }}$ spray application interval. This disease usually appears at seedling and flowering stages. It was recorded at both stages as reported (Farooq et $a l ., 2005)$. Disease was recorded visually and rated by using the following scale given by (Iqbal et al., 2005).

\begin{tabular}{ccc}
\hline Sr.No. & Response & Scale \\
\hline 1 & Highly Resistant & Less than $1 \%$ of plant wilted. \\
\hline 2 & Resistant & $1-10 \%$ of plants wilted. \\
\hline 3 & Moderately Resistant & $11-20 \%$ of plants wilted \\
\hline 4 & Susceptible & $21-50 \%$ of plants wilted \\
\hline 5 & Highly Susceptible & $51 \%$ or more of plants wilted
\end{tabular}

Disease incidence was calculated by the following formula:

\section{STATISTICAL ANALYSIS}

The statistical test was performed by using SAS statistical software. Means were sorted out by using Fisher's least significant difference (LSD) procedure (Steel et al., 1997).

\section{RESULTS}

The data analysis revealed that salicylic acid expressed statistically better results as compared to all others treatments. At in-vitro experiment 1, 2 and $3 \%$

$$
\text { Disease incidence (\%) } \frac{\text { Number of diseased plants }}{\text { Total number of plants inspected }} \times 100
$$

concentrations of salicylic acid showed minimum mycelial growth $(3.63,2.46$ and $1.14 \mathrm{~cm})$ followed by $\mathrm{KH}_{2} \mathrm{PO}_{4}(3.70,2.63$ and $1.8 \mathrm{~cm}), \mathrm{K}_{2} \mathrm{HPO}_{4}(3.76,2.50$ and $1.94 \mathrm{~cm})$, benzoic acid $(4.56,3.47$ and $2.2 \mathrm{~cm})$ and citric acid $(3.66,3.49$ and $2.3 \mathrm{~cm}$ ) while control expressed maximum mycelial growth $(5 \mathrm{~cm})$. Salicylic acid exhibited significant reduction in fungal growth colony at concentration of $3 \%$ followed by all other concentrations (Figure 1).

\section{Mycelial growth (cm)}

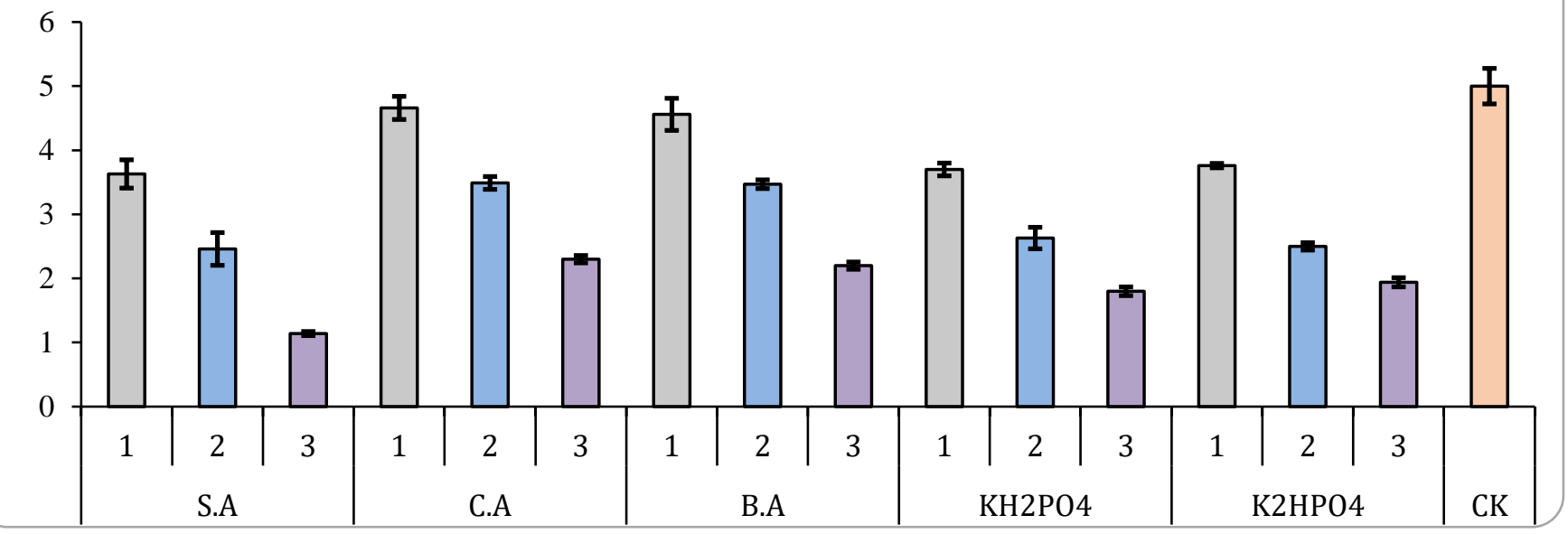

Figure. 1. Mycelial growth for $R$. solani culture incorporated with salicylic acid, citric acid, benzoic acid, $\mathrm{KH}_{2} \mathrm{PO}_{4}$ and $\mathrm{K}_{2} \mathrm{HPO}_{4}$ concentrations. S.A= Salicylic acid, C.A= Citric acid, B.A= Benzoic acid and CK= Control with 1, 2 and 3\% different concentrations.

Similarly, the effect of different plant activators on the growth of chilli plants showed that minimum root infection (4.34\%) was observed in salicylic acid and maximum infection (11.30\%) was observed in citric acid treated plants at concentration of $3 \%$ as compared to other concentrations (Figure 2). Maximum root and shoot length $(6.78$ and $17.88 \mathrm{~cm})$ was observed in case of salicylic acid at higher concentration while minimum (4.97 and $13.06 \mathrm{~cm}$ ) lengths of root and shoot were recorded in citric acid at same concentrations. Likewise, root and shoot weight (6.49 and8.50 gm) also expressed maximum growth in case of salicylic acid treated plants followed by all other plant activators (Figure 3 ). 


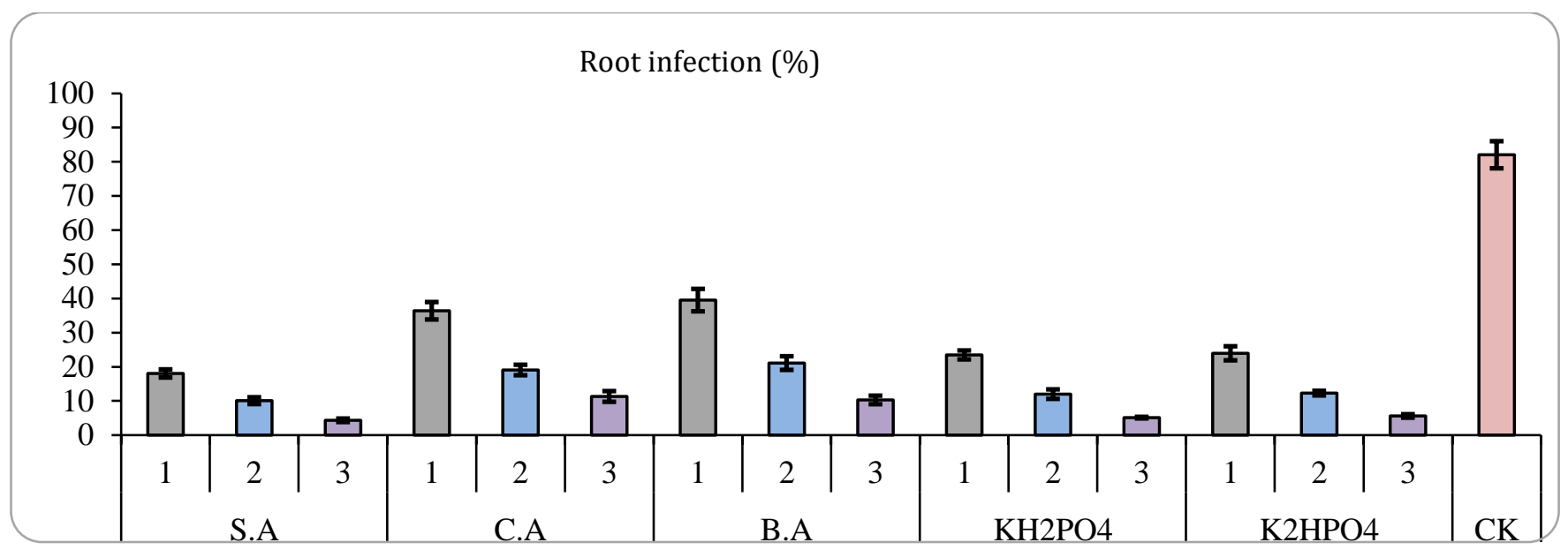

Figure 2. Efficacy of plant activators on root infection (\%) caused by R. solani. S.A= Salicylic acid, C.A= Citric acid, B.A= Benzoic acid and CK= Control with 1,2 and 3\% different concentrations.
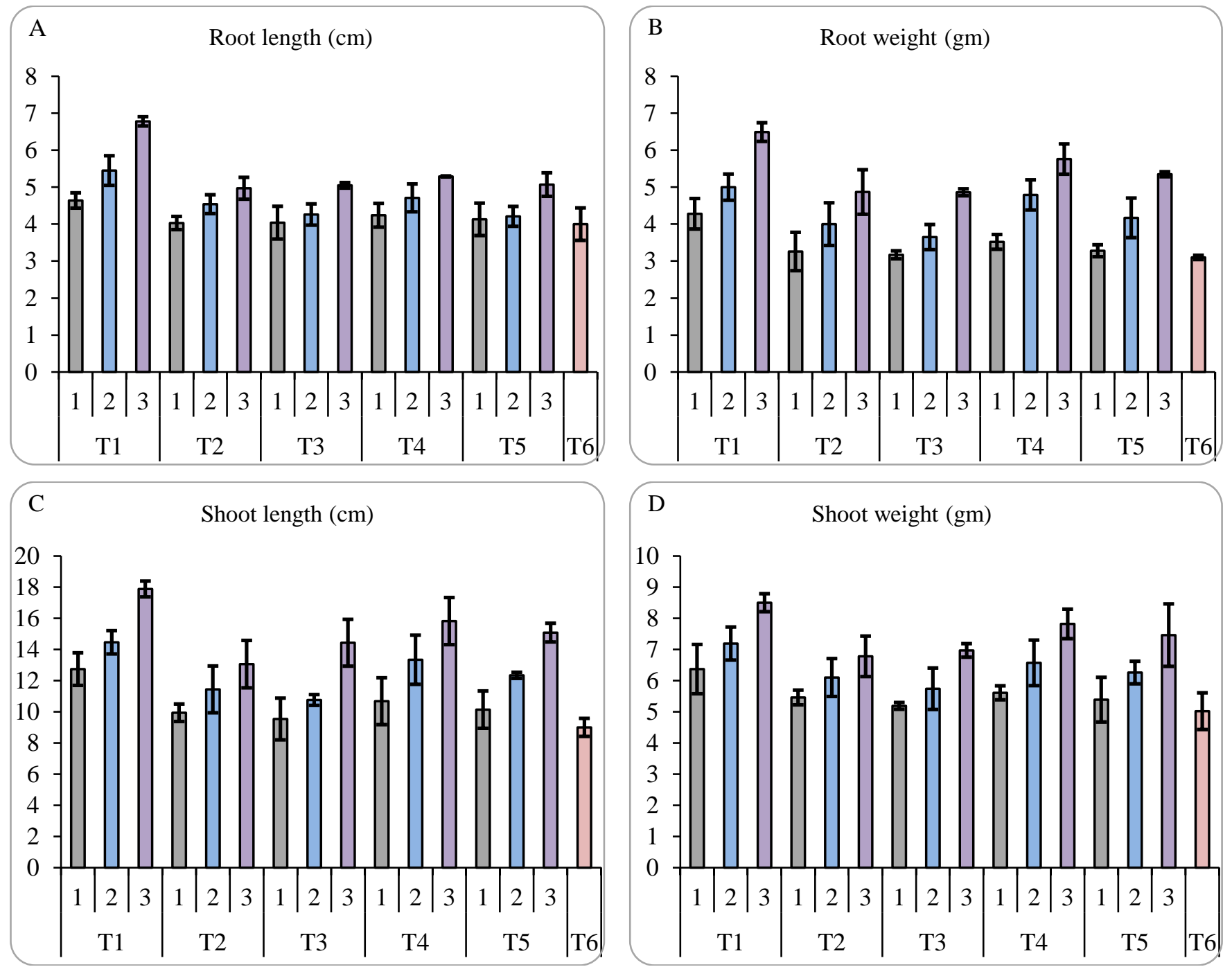

Figure 3. Effect of plant activators on plant growth and disease development. T1= Salicylic acid, T2= Citric acid, T3= Benzoic acid, $\mathrm{T} 4=\mathrm{KH}_{2} \mathrm{PO}_{4}, \mathrm{~T} 5=\mathrm{K}_{2} \mathrm{HPO}_{4}$ and $\mathrm{T} 6=$ control with 1,2 and $3 \%$ different concentrations. 
The statistical analysis showed that 3rd application of salicylic acid after 21 days of interval minimum disease incidence was recorded as compared to others applications after consecutive days. Concentration of $3 \%$ after 21 days of spraying salicylic acid showed
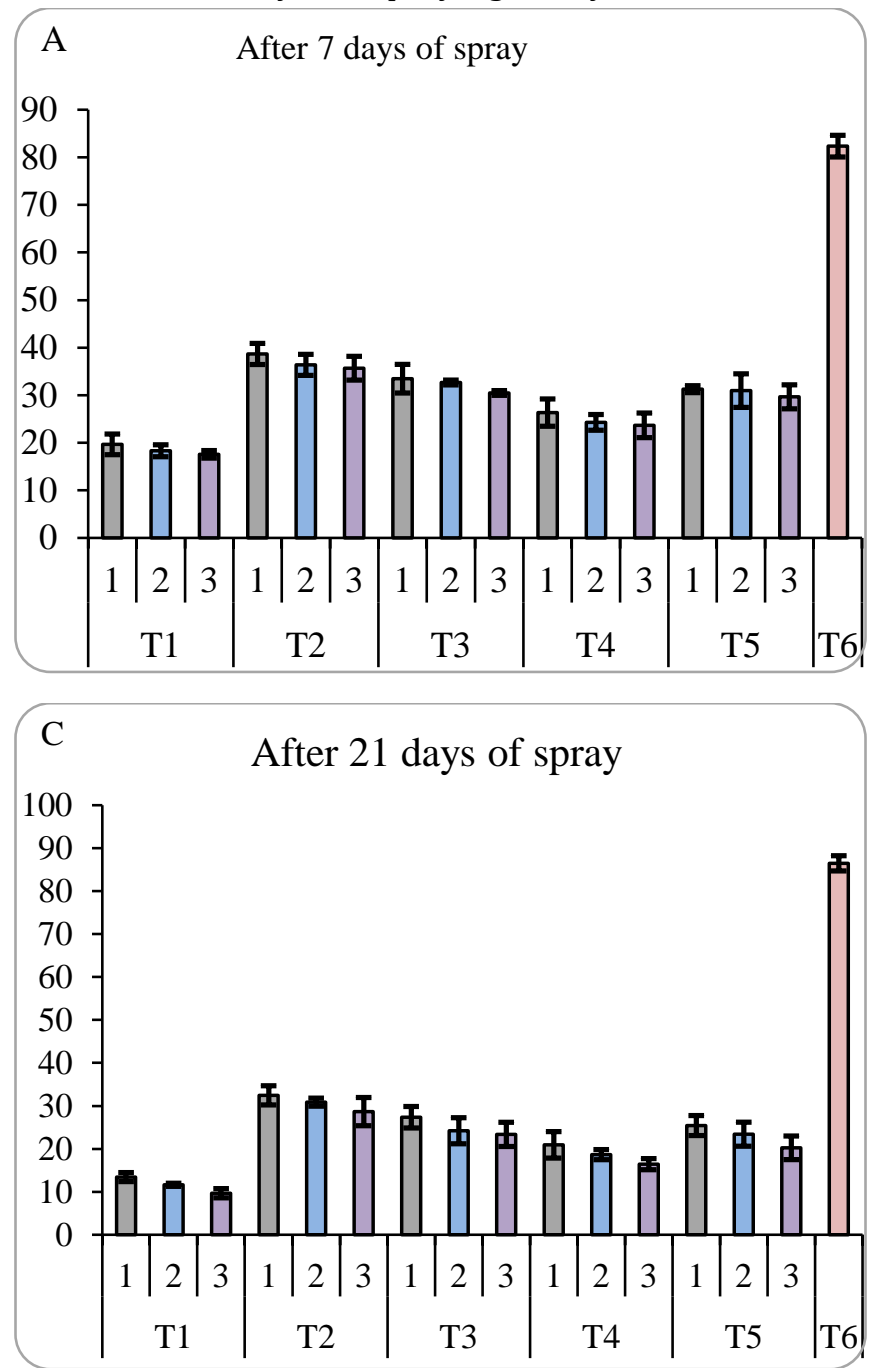

minimum disease incidence $(9.667 \%)$ followed by $\mathrm{KH}_{2} \mathrm{PO}_{4}(16.433 \%), \mathrm{K}_{2} \mathrm{HPO}_{4}(20.241 \%)$, benzoic acid (23.367\%) and citric acid (28.667\%) while control expressed maximum disease incidence $86.467 \%$ (Figure 4).
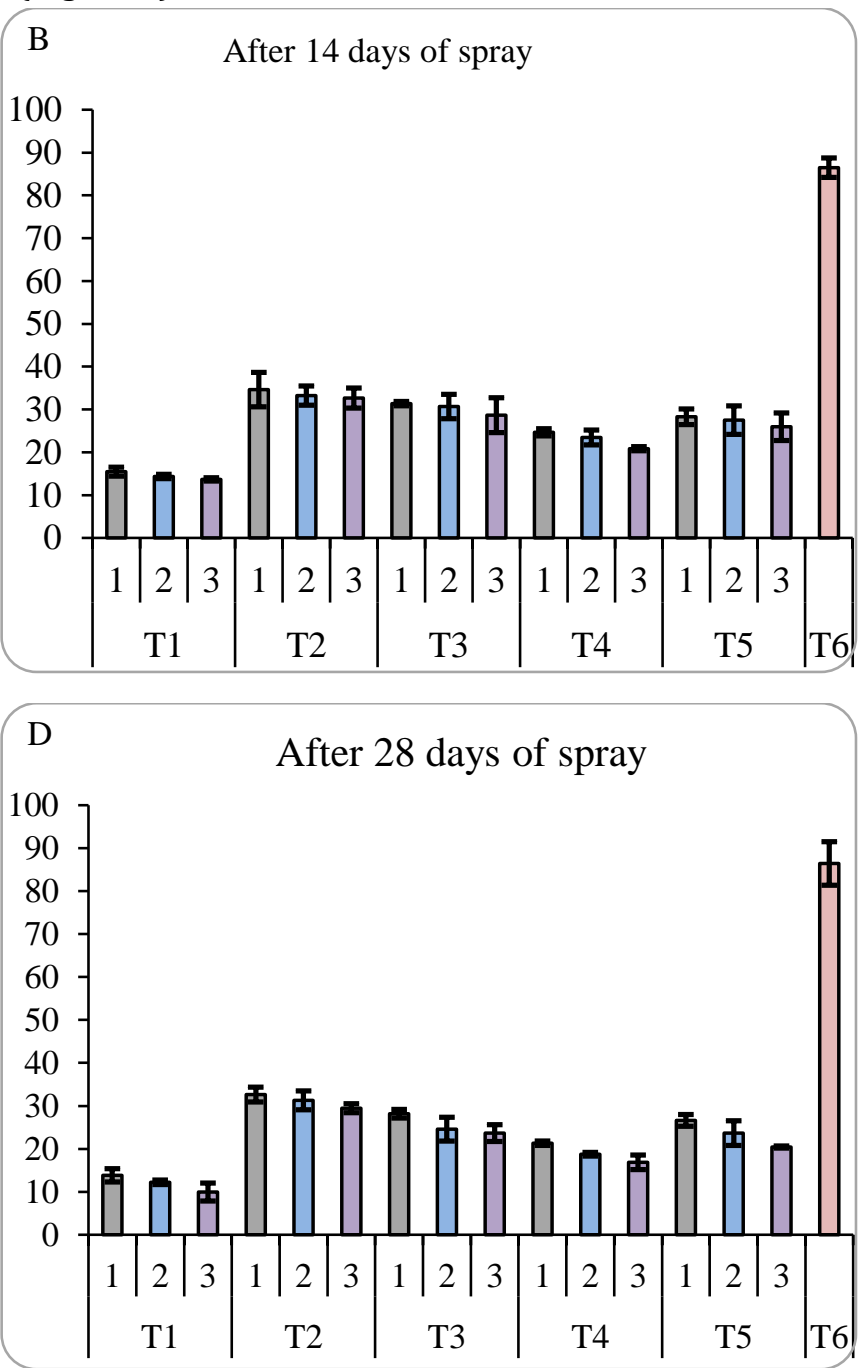

Figure 4. Effect of plant activators on disease incidence (\%) of $R$. solani . T1= Salicylic acid, $\mathrm{T} 2=$ Citric acid, $\mathrm{T} 3=$ Benzoic acid, $\mathrm{T} 4=\mathrm{KH}_{2} \mathrm{PO}_{4}, \mathrm{~T} 5=\mathrm{K}_{2} \mathrm{HPO}_{4}$ and $\mathrm{T} 6=$ control with 1,2 and $3 \%$ different doses.

\section{DISCUSSION}

To understand the biochemical modifications result to defensive conditions which could permit the development of the transgene with improved disease resistance or else innovative sort of plant defensive chemicals acting as stimuli to plant genetics for disease resistance tools (Ryals et al., 1996). In this study five plant activators salicylic acid, potassium dihydrogen phosphate $\left(\mathrm{KH}_{2} \mathrm{PO}_{4}\right)$, di-potassium hydrogen phosphate $\left(\mathrm{K}_{2} \mathrm{HPO}_{4}\right)$, benzoic acid and citric acid were evaluated with three different concentrations (1, 2 and 3\%). It was noted that, salicylic acid at all concentrations $(1,2$ and $3 \%)$ significantly (Ps 0.05) decrease the mycelial growth, root infection, shoot infection and disease incidence as compare to other plant activators but 3\% concentration is significantly more effective than other concentrations. Plants treated with salicylic acid showed best growth followed by all other plant activators. Benzoic acid performance is better than citric acid; $\mathrm{KH}_{2} \mathrm{PO}_{4}, \mathrm{~K}_{2} \mathrm{HPO}_{4}$ while citric acid is better than $\mathrm{KH}_{2} \mathrm{PO}_{4}$, $\mathrm{K}_{2} \mathrm{HPO}_{4}$ and $\mathrm{KH}_{2} \mathrm{PO}_{4}$ showed better results than $\mathrm{K}_{2} \mathrm{HPO}_{4}$. In tobacco and cucumber plants salicylic acid play a vital 
role to induce the conventional SAR (Yalpani et al., 1991). Salicylic acid induces resistance through activating signal molecule and helps to trigger plant defense gene expression (Enyedi et al., 1992). Salicylic acid enhances both localized acquired resistance (LAC) and systemic acquired resistance (SAR) in plants (Hammerschmidt et al., 2001). In chickpea salicylic acid induced PR protein that increases resistance against black gram diseases (Ramanathan and Vidhyase, 2002). Salicylic acid reliant on signaling pathway that leads to systemic manifestation of wide range spectrum and long-term disease resistance that is effective against different fungi and other pathogens (Heil and Bostock, 2002).

\section{REFERENCES}

Agrios, G. N. 2005. Plant Diseases Caused by Fungi. Plant Pathology. Elsevier, pp. 385-614.

Amer, M. 1995. Evaluation of adjuvants to enhance fungicide efficacy against plant pathogens.

Bosland, P. W. and E. J. Votava. 2012. Peppers: vegetable and spice capsicums. CABI.

Chandra, S., S. Chatterje and K. Acharya. 2010. Biological control of fruit rot and die back diseases of Capsicum annuum with Pseudomonas aeruginosa WS-1. Asian Australa's Journal of Plant Sciences and Biotechnology, 4: 38-42.

Chang, M.-S., J.-G. Kim and G.-H. Kim. 2011. Quality Characteristics of Fresh-cut Lotus Roots According to the Temperature of the Wash Water. Korean Journal of Food Preservation, 18: 288-293.

Dalvi, U., R. Naik and A. Kale. 2017. Antioxidative Enzyme Responses against Fusarium wilt (Fusarium oxysporum f. sp. ciceris) in Chickpea Genotypes. Annual Research \& Review in Biology, 12: 1-9.

Enyedi, A. J., N. Yalpani, P. Silverman and I. Raskin. 1992. Signal molecules in systemic plant resistance to pathogens and pests. Cell, 70: 879-886.

Farooq, S. 2005. Physiological studies of Fusarium oxysporum f. sp. ciceri. International Journal of Agriculture and Biology (Pakistan).

Hammerschmidt, R., J.-P. Métraux and L. Van Loon. 2001. Inducing resistance: a summary of papers presented at the First International Symposium on Induced Resistance to Plant Diseases, Corfu, May 2000. European Journal of Plant Pathology, 107: 1-6.
Heil, M. 2002. Induced Systemic Resistance (ISR) Against Pathogens in the Context of Induced Plant Defences. Annals of Botany, 89: 503-512.

Hunt, M. D., J. A. Ryals and D. Reinhardt. 1996. Systemic acquired resistance signal transduction. Critical Reviews in Plant Sciences, 15: 583-606.

Hussain, F. and M. Abid. 2011. Pest and diseases of chilli crop in Pakistan: A review. Int. J. Biol. Biotech, 8: 325-332.

Iqbal, S., C. Rauf, A. Bakhsh and U. Iqbal. 2005. Variability in F. oxysporum f. sp. ciceris. Mycopathologia, 3: 47-51.

Muhyi, R. and P. W. Bosland. 1995. Evaluation of Capsicum germplasm for sources of resistance to Rhizoctonia solani. HortScience, 30: 341-342.

Ramanathan, A., P. Vidhasekaran and R. Samiyappan. 2000. Induction of defense mechanisms in green gram leaves and suspension-cultured cells by Macrophomina phaseolina and its elicitors/Induktion von Resistenzmechanismen in Blättern von Mungbohnen und in Suspensions zellkulturen durch Macrophomina phaseolina und seinen Elicitoren. Zeitschrift für Pflanzenkrankheiten und Pflanzenschutz/Journal of Plant Diseases and Protection: 245-257.

Ryals, J. A., U. H. Neuenschwander, M. G. Willits, A. Molina, H.-Y. Steiner and M. D. Hunt. 1996. Systemic acquired resistance. The plant cell, 8: 1809.

Sanogo, S. 2003. Chile Pepper and The Threat of Wilt Diseases. Plant Health Progress.

Singh, R. 2007. Nematode development and biochemical changes in genotypes of chilli (Capsicum spp.) infected with root-knot nematode (Meloidogyne incognita race 1). Indian Agricultural Research Institute New Delhi.

Steel, R., J. Torrie and D. Dickey. 1997. Principles and procedures of statistics: a biometrical approach., 3rd edn (McGraw-Hill: New York).

Yalpani, N., P. Silverman, T. M. A. Wilson, D. A. Kleier and I. Raskin. 1991. Salicylic Acid Is a Systemic Signal and an Inducer of Pathogenesis-Related Proteins in Virus-Infected Tobacco. The Plant Cell, 3: 809.

Zote, K., M. Haware, S. Jayanthi and J. N. Rao. 1996. Effects of inoculum density of Fusarium oxysporum f. sp. ciceri race 1 and 2 on chickpea wilt. Phytopathologia Mediterranea: 43-47. 